$\begin{array}{lll}\text { KULTURA } & \begin{array}{l}\text { POLSKA A KADEMIA NAUK } \\ \text { KOMITET SOCJOLOGII }\end{array} & \text { ISSN 0023-5172 } \\ \text { i } & \begin{array}{l}\text { INSTYTUT STUDIÓW POLITYCZNYCH } \\ \text { SPOLCZENSTWO }\end{array} & \\ 2018, \text { nr } 2 & \text { PRZEMIANY WIĘZI }\end{array}$

MICHAŁ $\ Y S Z C Z A R Z$

Uniwersytet Warmińsko-Mazurski w Olsztynie

\title{
POLSCY TATARZY W PODLASKICH MEDIACH PUBLICZNYCH*
}

\section{WPROWADZENIE}

Zasadniczym i niezmiennym obowiązkiem nadawców mediów publicznych pozostaje prowadzenie działalności misyjnej. Nie zmieniło tego $\mathrm{w}$ zasadzie uchwalenie w latach 2015-2016 dwóch Ustaw o zmianie ustawy o radiofonii $i$ telewizji, które były pomyślane jako przygotowanie do gruntownej przebudowy ładu medialnego w Polsce ( $w$ ramach planowanej przez rząd tzw. dużej ustawy medialnej). Wielokrotnie nowelizowana Ustawa o radiofonii i telewizji z 1992 roku określa działalność misyjną jako konieczność zapewnienia całemu społeczeństwu i poszczególnym jego częściom zróżnicowanych programów w zakresie informacji, publicystyki, kultury, rozrywki, edukacji i sportu. Cechować je powinien pluralizm, bezstronność, wyważenie i niezależność oraz innowacyjność, wysoka jakość i integralność przekazu ${ }^{1}$. Z perspektywy problematyki etnicznej duże znaczenie ma przede wszystkim zapis mówiący o konieczności uwzględniania potrzeb mniejszości narodowych i etnicznych oraz społeczności posługującej się językiem regionalnym, w tym emitowania programów informacyjnych w językach mniejszości narodowych i etnicznych oraz języku regio-

Adres do korespondencji: michal.lyszczarz@interia.pl

* Podstawą artykułu jest tekst ogłoszony podczas XVI Ogólnopolskiego Zjazdu Socjologicznego (wrzesień 2016) w grupie tematycznej zatytułowanej „Etniczne wyzwania naszych czasów”.

${ }^{1}$ Dz.U. z 1993, nr 7, poz. 34 z późn. zm. art. 21. 
nalnym ${ }^{2}$. Działalność ta finansowana jest w zasadzie $z$ funduszy pochodzących $z$ opłat abonamentowych za używanie odbiorników RTV.

Obecność mniejszości narodowych i etnicznych w mediach publicznych stała się zauważalna zwłaszcza po wejściu w życie przepisów Ustawy o mniejszościach narodowych $i$ etnicznych oraz o jezyku regionalnym z 2005 roku, która dotychczasowym powinnościom nadała rangę zadania wynikającego z misji publicznej ${ }^{3}$. Regulacjom prawnym sprzyjał obserwowany od kilkunastu lat generalny wzrost świadomości etnicznej i regionalnej oraz aktywność popularyzatorska przedstawicieli poszczególnych wspólnot. Konsekwencją tego stanu rzeczy stało się zainteresowanie problematyką mniejszości ze strony medioznawców ${ }^{4}$. Dotychczasowe badania wskazują zwłaszcza na potrzebę analizy zależności zachodzących na styku kultur oraz podejmowania międzynarodowych studiów porównawczych. Istotnym polem badawczym stała się przy tym analiza elementów wpływających na kształtowanie wzajemnych relacji między większością a mniejszością. Zapisana we wspomnianych aktach normatywnych wyjątkowa rola mediów publicznych powinna znajdować wyraz między innymi w informowaniu o życiu i problemach mniejszości, integrowaniu członków wspólnoty i popularyzowaniu ich dziedzictwa kulturowego i językowego, a także w kształtowaniu pozytywnego wizerunku danej społeczności, co miałoby wpływać na ocieplenie wyobrażeń dotyczących jej członków w świadomości odbiorców. Funkcjonowanie tych zapisów postaram się prześledzić na przykładzie obecności w mediach publicznych polskich Tatarów, co nie było dotychczas przedmiotem pogłębionych analiz ${ }^{5}$.

Temat ten zostanie podjęty na podstawie analizy materiału dźwiękowego i wizualnego $z$ lat 2014-2017, pochodzącego $z$ archiwów cyfrowych Radia Białystok i białostockiego Oddziału Telewizji Polskiej (dostępne na stronach internetowych podlaskich mediów publicznych) oraz ze zbiorów prywatnych redaktora Józefa Wierzby. Cennym źródłem danych jakościowych dotyczących problematyki realizacji programów dla mniejszości narodowych i etnicznych stało się siedem wywiadów eksperckich przeprowadzonych z:

— dziennikarzami Radia Białystok (Adam Klimiuk, 25 maja 2015; Michał Stepaniuk, 24 maja 2015);

— reporterami związanymi z podlaskim oddziałem Telewizji Polskiej (Agnieszka Giełażyn-Sasimowicz, 9 kwietnia 2016; Adam Jakuć, 9 kwietnia 2016; Dariusz Szada-Borzyszkowski, 10 kwietnia 2016; Józef Wierzba, 16 maja 2016, szerzej zob. Łyszczarz 2017a);

2 Tamże, art. 21 ust. 1 a pkt 8 a.

${ }^{3}$ Dz.U. z 2005, nr 17, poz. 141 z późn. zm. art. 35.

${ }^{4}$ Szerzej o mniejszościach narodowych i etnicznych w polskim systemie medialnym zob. m.in.: Adamik-Szysiak, Godlewska 2014; Glensk, Kalczyńska 2004; Klimkiewicz 2003; Ratajczak 2007, 2010; Sadowski, Skoczek 2001; Szymańska, Hess 2014; Zawistowska 2007.

${ }^{5}$ Szerzej o polskich Tatarach zob. m.in.: Warmińska 1999; Radłowska 2017; Łyszczarz 2013, 2017b. 
— oraz z Arturem Konopackim - przedstawicielem społeczności polskich Tatarów, a zarazem działaczem Związku Tatarów RP i członkiem Komisji Wspólnej Rządu i Mniejszości Narodowych i Etnicznych (23 maja 2015, 10 kwietnia 2016).

Przeprowadzono również analizę dokumentów i aktów prawnych, w tym uchwał Rad Programowych działających przy rozgłośni Polskiego Radia w Białymstoku oraz terenowym oddziale TVP w Białymstoku (zob. bibliografia).

\section{PROBLEMATYKA TATARSKA NA ANTENIE REGIONALNEJ ROZGŁOŚNI POLSKIEGO RADIA W BIAŁYMSTOKU}

Tatarzy w Polsce są małą społecznością. Nie mają własnego programu w paśmie dla mniejszości narodowych i etnicznych $\mathrm{w}$ Radiu Białystok ${ }^{6}$. W paśmie tym wyraźnie dominują Białorusini - najliczniejsza i najlepiej zorganizowana wspólnota na Podlasiu. Program dla tej społeczności nadawany jest codziennie (Pod znakiem Pogoni), w sobotę uzupełnia go rozrywkowa audycja pt. Piosenka na życzenie. W języku białoruskim nadawane są również magazyny religijne związane z Cerkwią prawosławną (w niedzielę Przed wyjściem do Cerkwi, a w sobotę Duchowe spotkania). We wtorek, czwartek i niedzielę emitowany jest Litewski magazyn radiowy (początkowo pod nazwą Głos polskich Litwinów). Audycją społeczno-kulturalną o podobnym charakterze jest Ukraińska dumka (poniedziałek, środa i niedziela). Programem o szerokiej formule, poświęconym zróżnicowaniu kulturowemu regionu, jest nadawany co trzeci poniedziałek miesiąca magazyn Po sąsiedzku (do września 2016 pod nazwą Na pograniczu). Jest to jedyna audycja o mniejszościach dla większości emitowana w języku polskim. Wyłącznie na jej potrzeby realizowane są materiały dotyczące małych mniejszości, to jest Tatarów, Romów, Rosjan i Żydów. Program ten ma bardzo pojemną formułę i dociera do szerokiego grona słuchaczy, ale społeczność tatarska nie jest $\mathrm{w}$ nim prezentowana zbyt często. Od 1 września 2014 r. do 7 września 2015 r. wątki tatarskie stanowiły w tym programie 8\% (12 ze 150 poruszanych tematów, szerzej zob. Łyszczarz 2016, s. 85-90). Ma na to wpływ przede wszystkim cel nadrzędny redakcji, którym jest raczej nie przedstawianie życia mniejszości, lecz promowanie wielokulturowości regionu. Niewielki udział czasu antenowego poświęcanego Tatarom odzwierciedla potencjał tej grupy $\mathrm{w}$ porównaniu z innymi mniejszościami Podlasia.

${ }^{6}$ Początki pasma dla mniejszości w Radiu Białystok sięgają lat pięćdziesiątrych minionego stulecia, kiedy pojawiły się pierwsze programy w języku białoruskim. Pierwszą tego typu audycją był ukazujący się dwa razy w tygodniu Magazyn białoruski. Jego realizacja wiąże się z osobą Macieja Musy Konopackiego - nestora polskich Tatarów i niestrudzonego popularyzatora Tatarszczyzny — który w latach 1958-1960 pracował w białostockiej rozgłośni (Berger 2013, s. 40). 
Za realizację felietonów o tematyce tatarskiej w programie $\mathrm{Na}$ pograniczu odpowiadał Adam Klimiuk, który w następujący sposób wspomina początki swojej pracy:

Mam Tatarów pomimo tego, że nie jestem przedstawicielem tej mniejszości. Z wyksztatcenia jestem historykiem, interesowatem się jednak osadnictwem tatarskim, więc jakimś trafem dostałem tę dziatkę. Gdyby w redakcji byt ktoś $z$ tej mniejszości, to pewnie realizowatby te programy, a tak z konieczności padło na mnie. Wcześniej Tatarami zajmowali się wszyscy, co negatywnie odbijało się na naszej pracy.

Klimiuk przypomniał sobie, że $\mathrm{w}$ przeszłości podjęto pewne starania na rzecz stworzenia oddzielnego programu dla polskich Tatarów:

Kilka lat temu przychodził do Radia Józef Konopacki ${ }^{7}$, który zachęcat nas do tego, abyśmy stworzyli oddzielny program dla Tatarów. Nic jednak z tego nie wyszło, bo kierownictwo obawiato się, że trudno będzie zapetnić materiatem taka wytacznie tatarską audycję. Wtedy, tych kilka lat temu, znacznie mniej się działo, Tatarzy nie byli tak bardzo aktywni kulturalnie. $Z$ drugiej strony nie by to także kłótni dzielacych środowisko tatarskie, nie było afery o Kurban Bajram ${ }^{8}$.

Powyższą informację potwierdził Artur Konopacki — syn Józefa — mówiąc:

Chcieliśmy, aby ktoś na stałe prowadzit programy o Tatarach. Ojciec miał ambitne plany. Chciał, żeby była to nie tylko kronika aktualnych wydarzeń, ale cośbardziej wartościowego. Myślat o programie, który głębiej odnositby się do naszej historii, kultury i religii. Niestety na jakimś etapie to utknęło. Na pewno nie byto w tym złej woli Radia Biatystok.

W trakcie wywiadu realizowanego na potrzeby moich badań Klimiuk zdradził również kulisy przygotowywania materiałów o tematyce tatarskiej do programu Na pograniczu:

Programy o Tatarach realizuję sam, społeczność nie wnika $w$ to, co robię, nie narzuca mi tematów, w żaden sposób mnie też nie cenzuruje. Mam petna swobodę działania. Jedynie podczas ostatnich kongresów Muzutmańskiego Zwiazku Religijnego, gdy pojawit się konflikt, to Tatarzy nie bardzo chcieli rozmawiać, starali się unikać dziennikarzy. Ja to rozumiem, nie obrażam się. Jestem osobą z zewnątrz, więc na te sprawy patrzę z dystansem, nie muszę się emocjonalnie angażować. Staram się zachować obiektywizm i sprawiedliwie relacjonować wydarzenia. [...] Tatarzy już mnie znaja, więc sami informuja mnie o nadchodzacych wydarzeniach. To niesamowicie ułatwia mi prace, bo nie ukrywajmy, to jest hermetyczne środowisko.

W materiałach dotyczących Tatarów coraz częściej omawiane są projekty społeczno-kulturalne finansowane $z$ funduszy ministerialnych i unijnych.

\footnotetext{
7 Józef Konopacki (1949-2012) był długoletnim zasłużonym działaczem Muzułmańskiego Związku Religijnego (MZR) oraz Związku Tatarów RP, działał w Radzie Wspólnej Katolików i Muzułmanów, współtworzył reaktywowany w latach dziewięćdziesiątych Dział Tatarski w Muzeum Ziemi Sokólskiej przy Sokólskim Ośrodku Kultury.

8 Respondent ma na myśli spór prawny z lat 2013-2014 wokół legalności rytualnego uboju zwierząt bez ich ogłuszania, na potrzeby kultu religijnego (arab. halal).
} 
O przyczynach zainteresowania Radia Białystok tą formą aktywności Klimiuk mówił:

Relacjonujemy te wydarzenia, bo maja charakter edukacyjny, adresowane sa do najmłodszych i z zaciekawieniem sa odbierane przez naszych stuchaczy. Kultura tatarska jest nadal postrzegana jako egzotyczna, dlatego ludzie chca ja poznawać. Relacjonujemy także spotkania promujące nowe wydawnictwa tatarskie. W tej materii Tatarzy sa bardzo aktywni. Często informacje o tych wydarzeniach emitujemy także w programie „Podróże po kulturze" ${ }^{9}$. Kiedyś gościliśmy w niej Selima Chazbijewicza ${ }^{10}$.

Radio Białystok, podobnie jak wszystkie media w Polsce, szeroko relacjonowało wydarzenia na Krymie związane z okupacją wojskową oraz będącą jej skutkiem inkorporacją półwyspu przez Federację Rosyjską. Jest to tym bardziej istotne, że na Podlasiu schronienie znalazła większość Tatarów krymskich przebywających w Polsce ${ }^{11}$. Zwrócono przy tym uwagę na pomoc zaoferowaną przez polskich Tatarów rodakom $z$ Krymu. Radio Białystok transmitowało konferencję prasową z dnia 11 czerwca 2014 r., którą zwołał mufti Tomasz Miśkiewicz w sprawie pomocy Tatarom krymskim i zapewnienia im możliwości legalnego pobytu w Polsce. MZR poparł wówczas starania o nadanie uciekinierom z Krymu statusu uchodźcy. Zarejestrowany materiał został wysłany do Warszawy, aby — w ramach umowy partnerskiej — mogły go wykorzystać ogólnopolskie programy Polskiego Radia oraz inne rozgłośnie regionalne. Radio Białystok zrealizowało również ponad dwudziestominutowy reportaż o sytuacji Tatarów krymskich na Podlasiu, w którym wskazano niebezpieczeństwa czyhające na Tatarów $\mathrm{w}$ razie deportacji ${ }^{12}$.

W paśmie dla mniejszości prezentowany jest tylko taki przekaz dotyczący islamu, który bezpośrednio wiąże się z Tatarami. Ciężar gatunkowy tych informacji jest różny. Na przykład relacje z Letniej Akademii Wiedzy o Tatarach umieszczane są wyłącznie $\mathrm{w}$ paśmie mniejszościowym, a w przypadku uroczystości religijnych święta Kurban Bajram zrealizowany został duży materiał do magazynu Na pograniczu oraz migawki do serwisów informacyjnych z regionu. Kwestię tę przybliżył Michał Stepaniuk:

\footnotetext{
${ }_{9}^{9}$ Podróże po kulturze to trzygodzinna audycja kulturalna, nadawana w niedzielne przedpołudnie, zawiera podsumowanie wydarzeń tygodnia.

10 Selim Chazbijewicz (ur. 1955) - ambasador RP w Kazachstanie (od 2017 r.), profesor Uniwersytetu Warmińsko-Mazurskiego w Olsztynie, współzałożyciel Związku Tatarów Polskich oraz Rady Wspólnej Katolików i Muzułmanów, działacz religijny (imam gminy wyznaniowej MZR w Gdańsku w latach 1996-2004), najwybitniejszy — obok Musy Czachorowskiego — współczesny poeta tatarski.

11 Według danych MZR, cytowanych przez Karolinę Radłowską (2017, s. 168), pod koniec 2016 roku na terenie Polski znajdowały się 24 rodziny Tatarów z Krymu (126 osób), z czego 17 (72 osoby) mieszkały w Białymstoku. Koordynacją działań związanych z pomocą uchodźcom zajęła się Lilla Świerblewska - wówczas członkini NK MZR, a od 2018 roku przewodnicząca gminy wyznaniowej w Białymstoku.

12 Reportaż Renaty Redy pt. Elegia o Tatarach z Krymu był emitowany w Radiu Białystok 28 listopada 2014 r., a 13 maja 2015 r. w ogólnopolskim Programie I Polskiego Radia.
} 
Relacjonujemy święta polskich Tatarów i staramy się mówić o ich obrzędowości religijnej. Tematyka muzutmańska interesuje nas zatem tylko $w$ tatarskim kontekście. Informacje dotyczace sytuacji politycznej na świecie czy zagrożenie terrorystyczne nas nie zajmuja. To jest temat dla redakcji aktualności. Ten watek pojawiat się między innymi w porannych rozmowach, ale nigdy nie byto to wiazzane $z$ Tatarami.

Szczególne zainteresowanie mediów świętem Kurban Bajram wynikało z tego, że od kilku lat obchody tej uroczystości stały się kontrowersyjne w związku $z$ nieuregulowaną do niedawna sytuacją prawną dotyczącą uboju rytualnego, a także pikietami protestacyjnymi obrońców zwierząt z Obywatelskiego Towarzystwa Ochrony Zwierząt „Animals”. Towarzysząca praktykom religijnym atmosfera skandalu spowodowała, że relacje z Kurban Bajram pojawiały się również $\mathrm{w}$ głównym paśmie informacyjnym. W podobny sposób Radio Białystok postąpiło w kwestii relacjonowania kongresów MZR. Konflikt o władzę w Związku i kwestionowanie pozycji muftiego Miśkiewicza doprowadziły do tego, że znaczenie tych wiadomości przekroczyło ramy programu Na pograni$c z u$. O problemach związanych z przygotowywaniem materiałów dotyczących animozji wewnątrz środowiska tatarskiego mówił Klimiuk:

Staramy się zachować bezstronność i obiektywizm, informujemy o sytuacji w Zwiazku, ale bez wzbudzania niepotrzebnej sensacji. Nie robiliśmy wywiadów z przedstawicielami skonfliktowanych stron, bo Tatarzy byli przeciwni upublicznianiu tych spraw.

\section{PROBLEMATYKA TATARSKA NA ANTENIE REGIONALNEGO ODDZIAŁU TELEWIZJI POLSKIEJ W BIAŁYMSTOKU}

W przeciwieństwie do Radia Białystok, w którym tematyka tatarska jest obecna w szerokiej formule programów dla mniejszości narodowych i etnicznych, w TVP3 Białystok Tatarom udało się uzyskać możliwość realizacji własnego programu etnicznego w paśmie przeznaczonym dla mniejszości ${ }^{13}$. Treści związane z życiem społeczno-kulturalnym i aktywnością religijną tej wspólnoty

${ }^{13}$ Historia pasma dla mniejszości etnicznych i narodowych w TVP3 Białystok jest znacznie krótsza niż podlaskiej rozgłośni Polskiego Radia. Ośrodek Telewizji Polskiej w Białymstoku powstał dopiero w lipcu 1996 roku, a stała emisja rozpoczęła się w grudniu 1997 roku. Początkowo problematyka mniejszości skupiona była w jednym dużym magazynie pt. Sami o sobie. Wydawcą-koordynatorem tego programu, emitowanego co tydzień w niedzielę, był Marek Liberadzki. W kwietniu 1999 roku została wyodrębniona audycja poświęcona Polakom na Wschodzie (powstał magazyn Łaczy nas Polska), a w 2003 roku ostatecznie zakończono nadawanie programu Sami o sobie. W to miejsce powstało sześć samodzielnych magazynów, które tworzą niedzielne pasmo dla mniejszości (z powtórką w środę). Cotygodniową emisję ma w nim: Tydzień białoruski, Przegląd ukrainski oraz Panorama litewska. Raz w miesiącu nadawane są: Tatarskie wieści (dawniej Podlaski Orient), My Romowie i Wiadomości rosyjskie (wcześniej jako Rosyjski głos, a następnie Rosyjski ekspres). Z białoruską, ukraińską, częściowo także rosyjską wspólnotą związany jest również program U źródet wiary. Ten magazyn, przygotowywany przez Cerkiew prawosławną, należy do pasma religijnego, a nie do bloku audycji dla mniejszości, jednak emitowany jest bezpośrednio przed nim, co powoduje, że ma podobne audytorium. 
znalazły się początkowo w audycji Sami o sobie. Realizacją felietonów tatarskich zajął się Józef Wierzba, który następująco wspominał początki pracy:

To był zupetny przypadek, bo wcześniej zajmowatem się Polakami na Wschodzie. [...] W marcu 1997 pojechatem po raz pierwszy do Tatarów zrobić materiat o Kurban Bajram do programu. Było z tym trochę kłopotu, bo kamera ujęła fragment rytualnego uboju. Nasz dyrektor techniczny bat się, że możemy mieć z tego powodu problemy. Program na szczęście się spodobat $i$ tak już zostało.

Początkowo Tatarzy dysponowali zaledwie 5 minutami raz na miesiąc. W 1999 roku audycję wydłużono do 7 i pół minuty miesięcznie ${ }^{14}$. Przez długi czas treści tatarskie $\mathrm{w}$ TVP3 Białystok były emitowane 13 razy $\mathrm{w}$ roku. W 2010 roku usunięto dodatkowy program podsumowujący rok, a w zamian wydłużono czas antenowy pozostałych tatarskich audycji (ostatni program Wierzby z 11 lipca 2010 r. trwał 9 minut i 18 sekund).

Po zakończeniu nadawania programu Sami o sobie Wierzba rozpoczął we wrześniu 2003 roku wydawanie własnego magazynu poświęconego wyłącznie Tatarom. Otrzymał on nazwę Podlaski Orient, która miała akcentować związek $z$ regionem oraz istotną rolę dziedzictwa kulturowego tej mniejszości. Program, w zamyśle twórcy, miał mieć charakter informacyjno-publicystyczny. Wierzba starał się łączyć ideę programu mniejszościowego dla Tatarów z szerszą koncepcją edukowania widzów przez przekazywanie rzetelnej wiedzy o życiu społeczności. Na początku audycja była ograniczona, ze względu na czas jej trwania, do jednego tematu przewodniego, po kilku latach, gdy wydłużono czas emisji, realizatorzy mogli pozwolić sobie na przygotowanie dwóch felietonów. Wizję Podlaskiego Orientu tak wspominał jego pierwszy redaktor:

Tatarzy nawet na Podlasiu sa rozproszeni, wspólnota potrzebuje takiego programu. Chciatem też, żeby ten program oglądali mieszkańcy Podlasia. Im więcej będa wiedziećo Tatarach, tym lepiej. W przypadku nietatarskich widzów chodziło mi nie tyle o sucha informację dotyczaca tego, co się tam aktualnie wydarzyto, lecz o to, żeby widzowie mogli oswoić się z ta mniejszością. Dlatego też kwestie oczywiste dla Tatarów cierpliwie tłumaczyliśmy, aby ludzie z zewnątrz, którzy nie znają Tatarów, mogli je zrozumieć. Na tym polega publicystyka.

W sierpniu 2010 roku Józef Wierzba przeszedł na emeryturę, a wydawanie programu, decyzją ówczesnej dyrektor Agnieszki Romaszewskiej-Guzy, przejął Dariusz Szada-Borzyszkowski. Nowy redaktor miał odmienną koncepcję jego realizacji, zależało mu na tym, aby program miał jednoznacznie publicystyczny charakter i w większym stopniu popularyzował tatarskość w świadomości ogółu widzów. Tłumaczył to następująco:

Zależało mi na tym - mówił Szada-Borzyszkowski - aby przesuną́ ciężar z informacji w kierunku publicystyki. Chciatem, żeby ten program miat mniej informacyjny charakter,

${ }^{14}$ Zmiana nastąpiła $\mathrm{w}$ związku $\mathrm{z}$ usunięciem z bloku dla mniejszości części niemieckiej, której realizację przejąć miał ośrodek w Olsztynie (do czego jednak nie doszło). 
$\dot{z}$ eby byt bardziej żywy $i$ atrakcyjny także dla nietatarskiego widza, którego nie interesuja aż tak bardzo relacje z życia wspólnoty. Chciałem po prostu zaciekawić Tatarami.

Oprócz modyfikacji koncepcji programu Szada-Borzyszkowski zmienił również jego nazwę na Tatarskie wieści:

Chciałem być uczciwy wobec Wierzby. - tłumaczył — Wiedziatem, że formuła moich programów będzie inna niż jego. Nie mogłem firmować tego, co on wymyślit. Chciatem się skupićna wattku popularyzatorskim, publicystycznym, odszedtem od kroniki wydarzeń z życia wspólnoty. Trzeba byto zatem zmienić nazwę. To była wyłącnie moja decyzja.

Autorska wizja Tatarskich wieści, którą realizował Szada-Borzyszkowski, spowodowała jednak nieporozumienia wewnątrz redakcji TVP3 Białystok. Wyraźne ukierunkowanie magazynu na publicystykę powodowało, że reporterzy Obiektywu ${ }^{15}$ mieli utrudnioną możliwość korzystania z materiałów wytworzonych dla bloku programów dla mniejszości. Wspominał o tym Szada-Borzyszkowski:

Unas wszystko było dopieszczone, każdy plan starannie przemyślany. To była — nie waham się tak tego określić - praca twórcza. „Obiektyw” chciat na szybko, na formę nie zwracat należytej uwagi. Raziło mnie to. Oczywiście mogli korzystać z materiału „Tatarskich wieśi”, tak jak wcześniej działo się to za Wierzby, bo przecież pracowaliśmy dla jednej firmy. Wspótpraca jednak nam się nie układała. [...] Kolegom z „Obiektywu” trudno byto wyciać $z$ mojego programu kilkudziesięciosekundowego newsa. Dochodzito do kuriozalnych sytuacji, gdy u Tatarów — na przykład z okazji kolejnego Kongresu MZR — pojawiaty się dwie ekipy z TVP3 Biatystok.

W okresie kierowania TVP3 Białystok przez Romaszewską-Guzy, we wrześniu 2011 roku, nastąpiło drastyczne obcięcie dotacji, którą ośrodek otrzymywał $z$ funduszy pochodzących $z$ abonamentu. W poszukiwaniu oszczędności dyrektorka postanowiła zdjąć $z$ anteny programy dla mniejszości litewskiej, rosyjskiej, tatarskiej i romskiej. Panorama litewska oraz Rosyjski głos dość szybko wróciły do ramówki pasma dla mniejszości, natomiast audycje My Romowie oraz Tatarskie wieści - pomimo protestów zgłaszanych przez organizacje mniejszościowe oraz Radę Programową TVP3 Białystok ${ }^{16}$ - na wznowienie emisji czekały ponad rok (od sierpnia 2011 do września 2012).

Szada-Borzyszkowski Przygotowywał program Tatarskie wieści w okresie niezwykle trudnym dla społeczności tatarskiej. Począwszy od 2012 roku, kiedy odbył się XVIII Nadzwyczajny Wszechpolski Kongres MZR, zakończony rozłamem Związku, TVP3 Białystok stanęła przed problemem, w jaki sposób odnieść się do konfliktu, który wybuchł wewnątrz środowiska polskich Tatarów.

15 Codzienny magazyn informacyjny w TVP3 Białystok.

16 Uchwała nr 1/2011 z dnia 27 września 2011 r. Rady Programowej TVP3 Białystok w sprawie niedostatecznego finansowania Oddziału, uniemożliwiającego realizację misji telewizji publicznej; Stanowisko Rady Programowej TVP3 Białystok z dnia 19 grudnia 2011 r. w sprawie niedostatecznego finansowania Oddziału, w szczególności w zakresie środków na realizację programów mniejszości narodowych i etnicznych (http://bialystok.tvp.pl/17412868/rada-programowa [19.02.2017]). 
Redaktor Szada-Borzyszkowski w następujących słowach przedstawił ocenę tej sytuacji:

Na pewno nie pracowało się łatwo. Miałem świadomość stopnia skomplikowania sytuacji. Wiedziałem, że muszę być maksymalnie obiektywny i nie angażować się po żadnej ze stron. Dlatego też starałem się, aby obydwie strony byty obecne $w$ programie. Jak rozmawiatem $z$ muftim Miśkiewiczem, to zaraz potem jechatem do Kruszynian. Konflikt postrzegatem jednak jako prywatna sprawę Tatarów, w programie ten wątek nigdy bezpośrednio się nie pojawit. Sytuacja była napięta, nie chciałem być arbitrem, nie miałem ambicji rozstrzygania winy. Bałem się tego, że mogę nieopacznie sprowokować eskalację antagonizmów, bo ludzie nas ogladali, cenili nasz program. Dlatego bytem bardzo ostrożny i unikatem prezentowania w „Tatarskich wieściach” spornych kwestii.

W kwietniu 2015 roku Zarząd Regionalnego Oddziału Telewizji Polskiej w Białymstoku podjął decyzję o zakończeniu współpracy z Szadą-Borzyszkowskim. Ówczesny dyrektor Grzegorz Sawicki zaprosił wówczas do siedziby TVP3 delegację Tatarów, w skład której weszli działacze Związku Tatarów RP (Jan Adamowicz, Artur Konopacki i Lilla Świerblewska), aby omówić przyszłość programu. Tatarzy stanęli w obronie dotychczasowego wydawcy i zaproponowali kompromis. Audycję miała prowadzić osoba ze społeczności Tatarów we współpracy z Szadą-Borzyszkowskim, który miał zostać konsultantem technicznym. Drogą do polubownego wyjaśnienia kwestii osoby prowadzącej Tatarskie wieści mogłoby być przejęcie produkcji programu przez zewnętrzny podmiot związany z Tatarami. Dyrektor nie zgodził się jednak na proponowane rozwiązania, argumentując, że magazyn może nie spełniać norm jakościowych ${ }^{17}$.

W maju 2015 roku program Tatarskie wieści został oficjalnie przekazany Agnieszce Giełażyn-Sasimowicz. Pierwsza audycja przygotowana przez nią została wyemitowana 14 czerwca 2015 r. (trwała 10 minut i 17 sekund). Mimo zmiany osoby prowadzącej miejsce zajmowane przez Tatarskie wieści w bloku programów dla mniejszości od wielu lat jest takie samo. Widoczne zmiany polegają na powolnym wydłużaniu magazynu. Wierzba w latach dziewięćdziesiątych dysponował jedynie około pięcioma minutami, a obecnie program wydłużył się do około dwunastu minut ${ }^{18}$.

Giełażyn-Sasimowicz pozostawiła nazwę i czołówkę magazynu, tłumacząc to następująco:

Widzowie się przyzwyczajaja, program ma wyrobiona markę i szkoda to likwidować. Wychodzę z zatożenia, że poprawia się rzeczy złe. „Tatarskie wieści” byty i są dobrym programem, więc nie ma potrzeby zmiany. Uznałam jednak, że czas, którym dysponuje, pozwala mi na zwiększenie liczby felietonów w magazynie. Kiedyś byt jeden 6-7-minutowy, ja

\footnotetext{
17 Nie byłoby to rozwiązanie precedensowe. Na takich zasadach funkcjonuje Panorama litewska realizowana przez R\&P New Media s.c. $z$ Suwałk.

18 Tatarskie wieści w marcu 2016 roku zajęły 5,2\% czasu antenowego w paśmie dla mniejszości emitowanym w TVP3 Białystok (tj. 23 minuty 16 sekund z 7 godzin 25 minut 44 sekund ogółem).
} 
natomiast realizuję co najmniej dwa 5-minutowe watki, czasem nawet trzy krótsze, jeżeli dostanę kilka dodatkowych minut.

Wraz z przyjściem Giełażyn-Sasimowicz nastąpiła przede wszystkim istotna zmiana $\mathrm{w}$ charakterze programu. Ponieważ pracuje ona również $\mathrm{w}$ redakcji Obiektywu, materiały tatarskie częściej są emitowane w paśmie informacyjnym. Obecnie w znacznie mniejszym stopniu opierają się na reportażu. Realizatorzy nie mają już zatem tak mocnego zacięcia publicystycznego jak w czasach Szady-Borzyszkowskiego. Potwierdzają to słowa Giełażyn-Sasimowicz:

Kiedyś to raczej z programu tatarskiego czasem coś trafiało do pasma informacyjnego. Teraz wątki tatarskie pojawiają się w „Obiektywie” niezależnie od „Tatarskich wieści”. Przykładem może być chociażby ostatnia sprawa bulwersujaca społeczność lokalna Kruszynian i okolicznych wsi, związana z planami budowy kurzej fermy.

Należy stwierdzić, że problematyka dotycząca polskich Tatarów jest prezentowana $\mathrm{w}$ podlaskich mediach publicznych na różne sposoby. Widoczne są zwłaszcza różnice dotyczące: charakteru programu (samodzielny magazyn dla mniejszości tatarskiej na antenie regionalnego oddziału Telewizji Polskiej w Białymstoku, a kilkuprocentowy udział w zbiorczej audycji o mniejszościach w Radiu Białystok), jego długości (kilkanaście minut w miesiącu w TVP3 Białystok i zaledwie kilka minut w miesiącu w Radiu Białystok) oraz bogactwa wykorzystywanych form dziennikarskich (w TVP3 Białystok między innymi wywiady, felietony publicystyczne, reportaże artystyczne i informacyjne, w Radiu Białystok natomiast głównie kronika wydarzeń z życia mniejszości). Widoczny, już na pierwszy rzut oka, dużo większy potencjał programu tatarskiego w TVP3 Białystok jest uwarunkowany tym, że każdy spośród trojga dotychczasowych autorów mógł realizować magazyn samodzielnie, według swojej autorskiej wizji.

Prezentowanie kultury oraz popularyzowanie aktywności społeczno-kulturalnej mniejszości etnicznych i narodowych należy do zasadniczych obowiązków mediów publicznych, co wynika z regulacji ustawowych dotyczących zakresu prowadzenia działalności misyjnej. Problematyka dotycząca polskich Tatarami obecna jest głównie w paśmie dla mniejszości narodowych i etnicznych emitowanym w białostockim oddziale Telewizji Polskiej i - w o wiele mniejszym stopniu - w Radiu Białystok. Okazjonalnie wątki związane z Tatarami ukazują się również w innych programach informacyjnych i publicystycznych, ale nie jest to przedmiotem tej analizy. Zagadnienia poruszane w paśmie etnicznym koncentrują się wokół propagowania informacji istotnych z perspektywy mniejszości, dotyczących tego, co wydarzyło się w ich środowisku. Działania te przybierają głównie formę kroniki wydarzeń z życia wspólnoty, w której relacjonowane są inicjatywy podejmowane przez organizacje tatarskie na rzecz popu- 
laryzowania wiedzy o kulturze, tradycji i religii. Ważne miejsce w programach tatarskich emitowanych $\mathrm{w}$ podlaskich mediach publicznych zajmuje także problem stanu oświaty oraz nauczania języka mniejszości. Wiele uwagi poświęca się na przykład lekcjom religii muzułmańskiej prowadzonym w Szkole Podstawowej nr 28 w Białymstoku ${ }^{19}$, a także próbom nauczania języka tatarskiego podejmowanym przez uciekinierów z Krymu ${ }^{20}$.

Działalność podlaskich mediów dotycząca popularyzacji mniejszości etnicznych i narodowych skierowana jest do szerokiego grona odbiorców i wykracza poza aktywność „dla mniejszości”. Radio Białystok oraz TVP3 Białystok, realizując misję nadawcy publicznego, doskonale promują różnorodność kulturową regionu. Wiedza „o mniejszościach” sprzyja integracji społecznej i budowaniu forum pluralistycznej debaty publicznej. Szczególną formą działań jest w tym wypadku walka $z$ wykluczeniem społecznym i przejawami nietolerancji czy wręcz rasizmu w życiu społecznym, które w ostatnich latach stały się wstydliwą przypadłością Białegostoku (Kącki 2015). Publiczne radio i telewizja szeroko informują o antydyskryminacyjnych inicjatywach podejmowanych przez organizacje pozarządowe, relacjonują festiwale, które krzewią kulturę ludową, a także propagują dialog międzyreligijny na pograniczu. Znaczenie działań podejmowanych na rzecz Tatarów podkreśla Giełażyn-Sasimowicz:

Wiele mówimy o tym, kim sa Tatarzy, jakie sq ich dzieje ijak wiele dobrego zrobili dla Polski. Mówimy o islamie, naszym islamie, który nikomu nie zagraża i jest tu obecny od kilkuset lat. Mam nadzieję, że dzięki temu nasi widzowie rozgranicza problemy wielkiej polityki od naszych spraw lokalnych.

\section{BIBLIOGRAFIA}

Adamik-Szysiak Małgorzata, Godlewska Ewa (red.), 2014, Media mniejszości_mniejszości w mediach, Wydawnictwo Uniwersytetu Marii Curie-Skłodowskiej, Lublin.

Berger Rafał, 2013, Maciej (Musa) Konopacki. Udręczenie tatarskościa, Stowarzyszenie Jedności Muzułmańskiej, Bydgoszcz.

Glensk Joachim, Kalczyńska Maria (red.), 2004, Regionalne i lokalne media w społeczeństwie wielokulturowym, Wydawnictwo Uniwersytetu Opolskiego, Opole.

Kącki Marcin, 2015, Białystok. Biała siła, czarna pamięć, Wydawnictwo Czarne, Wołowiec.

Klimkiewicz Beata, 2003, Mniejszości narodowe w sferze publicznej. Reprezentacje, praktyki i regulacje medialne, Wydawnictwo Uniwersytetu Jagiellońskiego, Kraków.

Łyszczarz Michał, 2013, Młode pokolenie polskich Tatarów. Studium przemian generacyjnych młodzieży $w$ kontekście religijności muzutmańskiej oraz tożsamości etnicznej, Katedra Socjologii UWM-Muzułmański Związek Religijny w RP, Olsztyn-Białystok.

\footnotetext{
19 Jest to jedyny w Polsce przypadek nauczania religii muzułmańskiej w publicznej szkole podstawowej.

${ }^{20}$ Polscy Tatarzy od kilkuset lat nie posiadają własnego etnolektu. Kroki podejmowane na rzecz nauki języka krymskotatarskiego są elementem działań wspierających proces pobudzania tożsamości wspólnoty. Liderzy społeczności starają się dążyć w ten sposób do rekonstruowania etniczności wokół idei solidarności panturkijskiej.
} 
Łyszczarz Michał, 2016, Audycje dla mniejszości narodowych $i$ etnicznych w Radiu Biatystok jako element działań wspierajacych wielokulturowość Podlasia, w: Michał Łyszczarz, Marek Sokołowski (red.), Radio w cyfrowym świecie. Regionalne rozgłośnie radiowe, Wydawnictwo Uniwersytetu Warmińsko-Mazurskiego, Olsztyn.

Łyszczarz Michał, 2017a, Serca zostawili na stepach, dusze oddali Polsce (wywiad $z$ dziennikarzem TVP Józefem Wierzba), „Rocznik Tatarów Polskich”, seria 2, t. IV (XVIII).

Łyszczarz Michał, 2017b, Specyfika medialnego dyskursu dotyczacego islamu i muzutmanów w Polsce, „Rocznik Tatarów Polskich”, seria 2, t. IV (XVIII).

Radłowska Karolina, 2017, Tatarzy polscy. Ciagłość i zmiana, Fundacja Sąsiedzi, Białystok.

Ratajczak Magdalena (red.), 2007, Multikulturalizm w sferze mediów, Wydawnictwo Uniwersytetu Wrocławskiego, Wrocław.

Ratajczak Magdalena, 2010, Różnorodność kulturowa w mediach. Doświadczenia europejskie, Elipsa, Warszawa.

Sadowski Andrzej, Skoczek Tadeusz (red.), 2001, Mniejszości narodowe i etniczne a media elektroniczne. Białoruś, Estonia, Litwa, Łotwa, Polska, Ukraina, Wydawnictwo Uniwersytetu w Białymstoku, Białystok.

Szymańska Agnieszka, Hess Agnieszka, 2014, Mniejszości narodowe, etniczne i religijne w przekazie mediów, Wydawnictwo Uniwersytetu Jagiellońskiego, Kraków.

Warmińska Katarzyna, 1999, Tatarzy polscy — tożsamość religijna i etniczna, Universitas, Kraków.

Zawistowska Alicja, 2007, Mniejszości w mediach: konteksty i granice prezentacji, „Pogranicze. Studia Społeczne", t. 13.

Stanowisko Rady Programowej TVP3 Białystok z dnia 19 grudnia 2011 r. w sprawie niedostatecznego finansowania Oddziału, w szczególności w zakresie środków na realizację programów mniejszości narodowych i etnicznych.

Uchwała nr 1/2011 r. z dnia 27.09.2011 r. Rady Programowej TVP3 Białystok w sprawie niedostatecznego finansowania Oddziału, uniemożliwiającego realizację misji telewizji publicznej.

Ustawa z dnia 29 grudnia 1992 r. o radiofonii i telewizji (Dz.U. z 1993, nr 7, poz. 34 z późn. zm.).

Ustawa z dnia 6 stycznia 2005 r. o mniejszościach narodowych i etnicznych oraz o języku regionalnym (Dz.U. 2005, nr 17, poz. 141 z późn. zm.).

Ustawa z dnia 30 grudnia 2015 r. o zmianie ustawy o radiofonii i telewizji (Dz.U. z 2016, poz. 25). Ustawa z dnia 25 lutego 2016 r. o zmianie ustawy o radiofonii i telewizji (Dz.U. z 2016, poz. 443). Ustawa z dnia 22 czerwca 2016 r. o Radzie Mediów Narodowych (Dz.U. z 2016, poz. 929).

\title{
THE POLISH TATARS IN PUBLIC MEDIA IN PODLASIE
}

\author{
Michał Łyszczarz \\ (University of Warmia and Mazury in Olsztyn)
}

\section{Summary}

This article concerns the Tatar community in Poland and its image in public media in Podlasie. Above all, the author considers the place of Tatar programs in the space reserved for national and ethnic minorities in the programming of Radio Białystok and the Białystok division of Polish Television. The author addresses the question of how these broadcasts are conducted and also cooperation between the media and the ethnic 
minority in the last dozen or more years. His conclusions are based on empirical material deriving from analysis of the content of the internet archives of the Podlasie public media, legal acts and documents, and qualitative interviews with representatives of the Tatar community and local media.

Key words / słowa kluczowe

Polish Tatars / polscy Tatarzy, public media in Poland / media publiczne w Polsce, Radio Białystok / Polish Radio in Białystok, Polish Television in Białystok / TVP3 Białystok 